\title{
マグネシウムと太陽光励起レーザーによる新エネルギーサイクル
}

\author{
矢部孝 \\ 東京工業大学 機械物理工学専攻（†152-8550 東京都目黒区大岡山2-12-1）
}

\section{A New Energy Cycle Utilizing Solar Pumped Laser and Magnesium}

\author{
Takashi YABE \\ Department of Mechanical Sciences and Engineering, Tokyo Institute of Technology, \\ 2-12-1 O-okayama, Meguro-ku, Tokyo 152-8550
}

(Received November 11, 2009)

\begin{abstract}
Securing energy storing media is an essential factor for utilizing solar power that needs to be leveled out for its spatial and temporal variation. Magnesium is the most promising material as an energy storming medium and carrier for an energy cycle, owing to its abundance, compactness, compatibility and versatility compared to other energy medium candidates such as hydrogen and biomass as well as other metals. Essential and unique technology for the energy cycle is the reduction process of magnesium from its oxidized form that requires four thousand degrees that is inaccessible merely by focusing natural sunlight. An energy qualifying process from solar to laser radiation, solar pumped laser, plays an essential role in the cycle. An overview of key technologies consisting of the energy cycle is given.
\end{abstract}

Key Words: Solar pumped laser, Magnesium fuel, Seawater desalination, Metal oxide reduction

\section{1. 緒 言}

太陽光のエネルギーは無尽蔵である。世界中の電力使 用量は, わずか数万 $\mathrm{km}^{2} の$ 面積に降り注ぐ太陽光のエネ ルギーでまかなえる。 サハラ砂漠の面積が860万 $\mathrm{km}^{2}$ な ので，そのエネルギーの巨大さが想像できるであろう. それでは, 現在非常に性能が上がってきている太陽電池 によってこの太陽光を利用することで十分なのであろう か? 困ったことに, 量りや雨を考慮すると, 我が国の 年間平均日照時間は4時間/日しかない. 太陽光だけで, 日本全体のエネルギーをまかなうには，国土の60\%に ものぼる太陽光受光面積が必要となる (太陽利用効率 $30 \%$ と仮定し, リスク回避で10日分の貯蔵を念頭にお いている).

世界中には，年間平均日照時間が10時間/日を越す国 があるが，そこからエネルギーを輸送してくる方法がな ければ他の国がこれを利用することはできない，即ち， エネルギー貯蔵ができ, 移動可能な媒体が必要となる。 年間100億トン消費している石油・石炭をこのエネル ギー貯蔵でまかなおうとすると, 当然数十億卜ン規模の 媒体が必要となってくる。 その媒体を製造するエネル ギーも考えなければならないので, 候補となる物質はほ とんど限られる.

著者は, マグネシウム $(\mathrm{Mg})$ を用いたエネルギー貯蔵
を提案した ${ }^{1,2)} . \mathrm{Mg}$ を酸素や水と反応させてエネルギー を取り出し, 反応生成物である酸化マグネシウムを太陽 光や風力などの自然エネルギーを用いて $\mathrm{Mg}$ に戻すこと ができれば, この $\mathrm{Mg}$ がエネルギーの貯蔵, 輸送媒体と なることが期待できる。このサイクルには一切，化石燃 料は関与せず, 地球温暖化の危険因子となるものが介在 しない(Fig. 1). 以下では, $\mathrm{Mg}$ を媒体とした再生可能エ ネルギーに関する研究開発の現状と将来への展望を述べ る.

\section{2. なぜマグネシウムか}

$\mathrm{Mg}$ の資源量は海水中でナトリウムに続いて2番目に多 く，地球の海水中に1800兆卜ンあると言われている。ま た，ゴビ砂漠やアリゾナの砂漠にはかなりの量の $\mathrm{Mg}$ が 含まれている。亜鉛の埋蔵量4億トン, アルミ150億卜 ン, 鉄8千億トンに比べても桁違いに大きい.

エネルギー貯蔵能力を考えると，単位体積当たりに発 生できる熱量は液体水素の5倍であるので，コンパクト なエネルギー源でもある。100万kWの発電所のわずか一 日分の燃料を蓄えるためだけでも，1気圧水素だと，高 さ10 mで $1 \mathrm{~km}$ 四方のタンクが必要である. $\mathrm{Mg}$ だと, 高 さ10 mで $15 \mathrm{~m}$ 四方と桁違いに小さい. ここで, 1 気圧の 水素としたのは, 1 気圧の圧力差では $1 \mathrm{~m}^{2} の$ 面積に 10 卜 


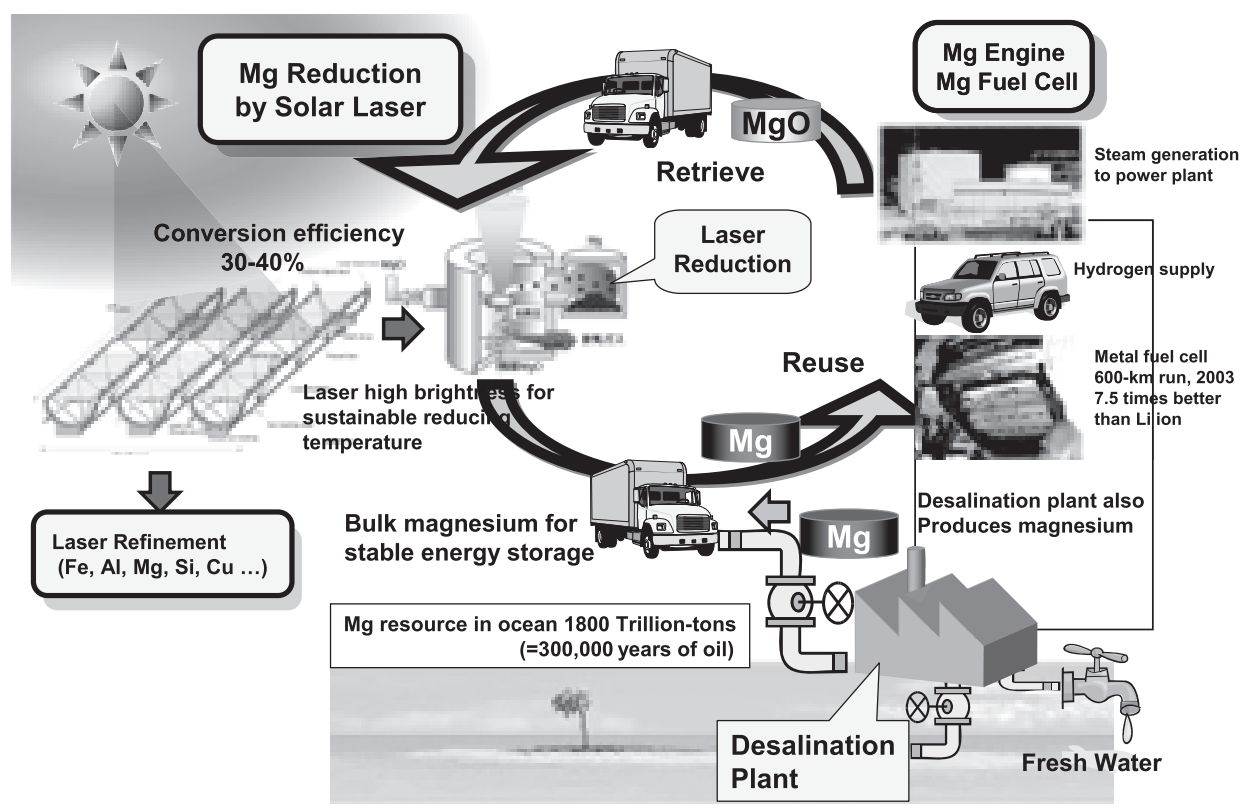

Fig. 1 Energy cycle using magnesium and solar pumped laser.

ンの力がかかるが，大きなタンクでは気圧差をつけるこ とができないので，大気圧で貯蔵するしかないからであ る. 自動車の例で考えると, 各ガソリンスタンドは車 200台分のガソリン $10 \mathrm{~m}^{3}$ 程度を蓄えている。 これを水素 と置き換えるとなんと $28,000 \mathrm{~m}^{3}$ のタンクが必要とな る. 日本中の地下が水素タンクになるであろう.

$\mathrm{Mg}$ の重量当たりの反応熱 (水素燃焼も含めて) は $25 \mathrm{MJ} / \mathrm{kg}$ であり, 石炭 $30 \mathrm{MJ} / \mathrm{kg}$ とほほ同程度である。現 在の火力発電所の燃料を $\mathrm{Mg}$ に替えることができれば, 蒸気タービンで発電する現在の火力発電所の化石燃料の 代わりに“リサイクル可能な石炭”としてMgを使うこと もできるので，既存のシステムを継承することができ る. Mgは, 引火の危険がなく, 大量のエネルギー貯蔵 に向いている.

別の利用方法はマグネシウム燃料電池 (空気電池)であ る。ちょっと聞きなれない言葉であろう。一般に, 燃料 電池というと水素燃料電池しか考えない人が多い。これ は, 水素を燃料として供給して, 酸素との反応で電池に なっている，燃料となる水素は常に外から供給されるの で, 効率が高くなる。一般に, 電池の効率は容器全体を 含めた電池の重量に対して, 発生することのできる電力 を言うが，金属電池は重量が重いために，効率が悪いと 信じられている。そここで, 重量の軽いリチウムイオン電 池が現在よく使われている。この効率は最高 $650 \mathrm{Wh} / \mathrm{kg}$ であるが，定常的には $200 \mathrm{Wh} / \mathrm{kg}$ と言われている.

ところが，燃料が外から供給される場合には，基本的 には燃料は無限にあると考えられるので, 容器の重さが 無視できるようになる，そのため，水素燃料電池の効率 も高くなるのである。そういう考えに立てば，金属も燃 料として外から供給できれば，金属そのものが持つ純粋 な能力を引き出すことができるようになる，米国の著者 らの共同研究者は, すでに亜鉛燃料電池を製作し, 1 回 の燃料供給で普通乗用車( ンンダ、インサイト)の
$600 \mathrm{~km}$ 走行に成功している(2003年，ギネス公認記 録)。しかも，燃料を供給することで，100回以上もこれ を繰り返せることを実証した。このときの亜鉛燃料電池 の効率は500 Wh/kgであった。これを $\mathrm{Mg}$ に替えると $1500 \mathrm{Wh} / \mathrm{kg}$ となることが分かっているので，今後が期待 できる技術である。

リチウムイオン電池のように電気を使って充電するよ うなものは，普通乗用車にはあまり薦められない，充電 が完了するまでドライバーが待てるかどうかは問題であ ろう。これに対して, 上述の亜鉛燃料電池では, 亜鉛 (将来は $\mathrm{Mg}$ ) 燃料パックの交換はわずか 3 分で済むし, 安 全性も高いので，コンビニでも販売でき，新たなインフ ラも必要としない，将来的にはリチウム空気電池も有望 だが，リチウム原子の性能が，比容量 $3.83 \mathrm{Ah} / \mathrm{g}$, 酸化還 元電位3 Vであるので, 最高 $11.5 \mathrm{kWh} / \mathrm{kg}$ が可能として も，500 km走行可能な $100 \mathrm{kWh}$ の電池を搭載する自動車 が，現在世界中にある9億台に達するには，780万トンの リチウムが必要である。これに対してリチウム埋蔵量 1100万トンはあまりにも少ない，また，現在年間リチウ 厶生産量は2万5千トンしかなく, それでもリチウム争奪 戦が繰り広げられている，大量にあるという海水資源で も， $1 \mathrm{~kg}$ 海水中に，0.1 $\mathrm{mg}$ しか含まれていないリチウム を石油に代わる燃料とするリスクを冒せるだろうか.

\section{3. マグネシウムの還元}

使用済みの $\mathrm{Mg}$ は酸化マグネシウム $\mathrm{MgO}$ という白い粉 末となって残るが，次はこれを元に戻すことが必要であ る。従来のMg製錬は, ドロマイト $\left(\mathrm{MgCO}_{3} / \mathrm{CaCO}_{3}\right)$ を焼 成して $\mathrm{CO}_{2}$ を飛ばし, $\mathrm{MgO}$ にケイ化鉄FeSi という還元郕 を使用して1200-1500度という比較的低温で行われてき ている，だが，還元剤を回収できないために，これを作 る資源とエネルギーを考えると, これをそのまま模倣し 
ても再生可能エネルギーとはなりえない，実際，世界の $\mathrm{Mg}$ の7割を生産しているピジョン法(熱還元法)では, Mg 1トンの生産にコークス10トンを使用しているので, $\mathrm{Mg}$ 燃料にするくらいなら，石炭をそのまま使った方 がはるかに環境にやさしい.

還元剤なしで，Mgを還元することは，そう容易なこ とではない. $\mathrm{MgO}$ の還元は, 蒸発の潜熱や分解に要す るエネルギーに打ち勝ちながら4000度という高温を実現 しなければならない。このエネルギーを単純に温度に換 算すると $2 万$ 度近くにもなる。このエネルギーを太陽光 で賄おうとしても, 太陽光の表面温度は6000度程度なの で，ただ陽光を集めるだけでは，このような分解を達 成できないことは明らかである。

確かに太陽炉内で4000度近い高温を実現したという報 告はある。しかし, これは単に加熱して到達した温度 (顕熱)だけである，先に述べたように，蒸発・分解に要 するエネルギーは顕熱にくらべ桁違いに大きいので，そ の状態で物質を高温に保つことは不可能である。著者 は，この太陽光をレーザーに変えることができれば，さ らにエネルギー集中を高め, 超高温を実現することがで きるであろうと考えた。 さらに，レーザーでは容器全体 を暖めずに局所的に高温を実現できるので，炉壁が超高 温となることはない.

例えば，太陽光が $1 \mathrm{~cm}$ 径の円状に集光されたと考え， その際に到達する温度が100度であったとしよう。レー ザーによって同じエネルギーが $1 \mathrm{~mm}$ 径に集光できれば 面積が100分の一となるので, 1 万度の高温が達成でき る．太陽は，光源が有限の大きさであるため，集光サイ ズの下限はこの光源の大きさで決定される。太陽をレー ザーという別の光に変換できればこの限界を超えること が可能となる.

面白いのは, $1 \mathrm{~mm}$ 径の局所的な部分だけが高温とな るので，そこから噴出して $1 \mathrm{~cm}$ 径まで膨張すると， 100 度まで温度が低下する。元々のエネルギーが $1 \mathrm{~cm}$ 径を 100度にする能力しかないので当然であろう。従って， 集光点から $1 \mathrm{~cm}$ 離れたところは低温となる。しかし， $1 \mathrm{~mm}$ 径の小さな領域だけでは生産量を増やすことがで きないので，実際には何100本のレーザーを $1 \mathrm{~cm}$ 間隔で 照射することになる。

熱伝導によって $\mathrm{MgO}$ 中を熱が伝わると思う人が多い が, レーザーアブレーションの知識がある人はそうでな いことが理解できる。レーザーエネルギーのほとんどは 噴出する蒸気によって持ち去られるので，内部にはほと んど伝わらない。このときに持ち去られるエネルギー は，蒸発の潜熱であり，運動エネルギーである，

我々のプロセスでさらに重要なことは，こうした相変 化を起こす領域を利用していることにある。通常，入射 エネルギーが増大すると温度が上昇する。輻射損失は温 度の4乗に比例して増大するので，このままでは，どこ かで輻射損失が優位となり，入射エネルギーがほとんど 外部へ放出され利用できない。しかし，蒸発・分解する 温度では，蒸発が継続している間温度上昇が停止するの で，すべての物質が蒸発してしまうまで，温度は沸点に
保たれる。これは，水の蒸発を思い出せば理解できると 思う。いくらエネルギーを注入しても温度が増大しない ため，輻射損失も増大しなくなる。このような状況を利 用すれば，入射エネルギーが有効に蒸発・分解に費やさ れる。

\section{4. 太陽光励起レーザー}

著者らは，フレネルレンズと二次集光系，レーザー媒 質の一体型システムを用いることにより，一度集光位置 を合わせれば後は再調整なしで太陽光を追跡しつつレー ザー発振することに成功した。実際に，2時間以上にわ たって連続的なレーザー発振に成功している ${ }^{3-5)}$

2007年7月 25 日に完成した $4 \mathrm{~m}^{2}$ の集光系(Fig. 2)では， レーザー出力 $80 \mathrm{~W}$ を得た。これは，フレネルレンズに 入力した太陽光 $4 \mathrm{~kW}$ の $2 \%$ に当たる。 まだまだ，小さい と思われるかもしれないが，作成したフレネルレンズに 気泡が入っていたため設計の集光効率の半分 $40 \%$ と なっていたこと，二次集光系でのレーザー媒質への吸収 が25\%であったことを考えると，吸収太陽光に対して レーザー出力は20\%を実現しているので, フレネルレ ンズと二次集光系の改良で，十分な効率を達成できるこ とが明らかとなった。ささら実験を元にしたレーザー理

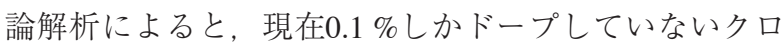
ムを $0.3 \% に$ 変更するだけで，2倍以上の出力を得ること ができると予測されている。従って，レーザー媒質の改 良と, 集光効率の向上によって 20 から $30 \%$ の効率は現 実の世界に入ってきていると言っても過言ではない.

実験室内での実験と実際の太陽を用いた屋外実験とは 本質的に違うことをここで強調しておきたい，実際の太 陽光を用いない実験なのに，太陽励起レーザーと称して いる論文は，問題の本質を全く理解していないと言わざ るを得ない，防振台の上に組まれたシステムと違い，装 置全体が風に摇られているので，入射太陽光の集光も完 全ではないことがほとんどである。こうした中で，ステ ンレス板を切断できる出力を確保したことの意義は大き い.

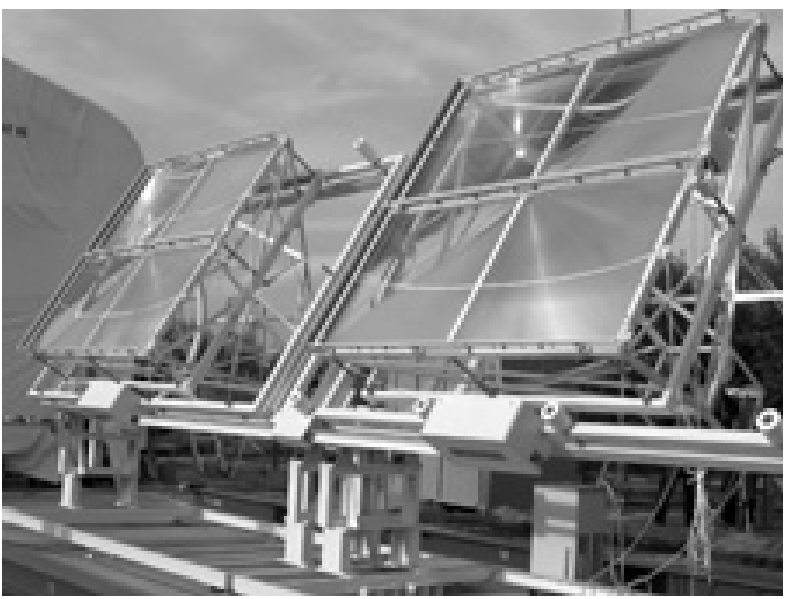

Fig. 2 A solar pumped laser system designed for onekilowatt laser output with $4-\mathrm{m}^{2}$ Fresnel lens solar concentrator (Chitose experimental site, Hokkaido). 


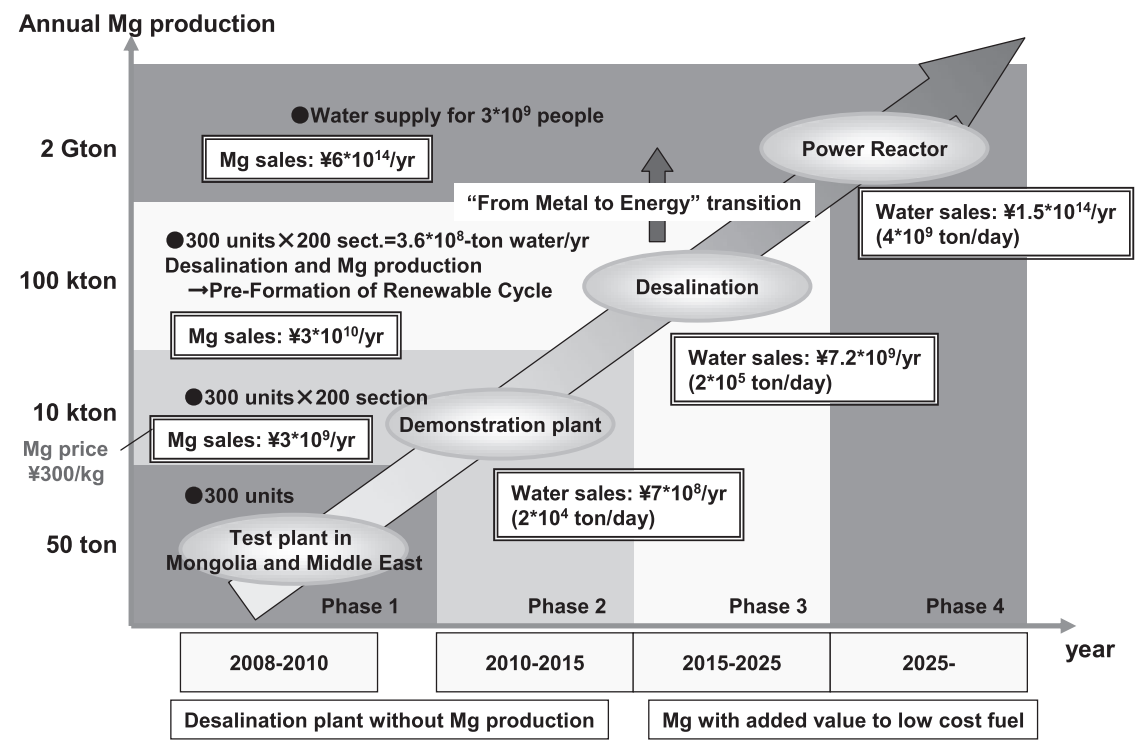

Fig. 3 Load map towards magnesium energy cycle and desalination plants.

実用的な太陽光励起レーザーの1ユニットは $2 \mathrm{~m} \times 2 \mathrm{~m}$ のフレネルレンズを用いたものとなるだろう。この面積

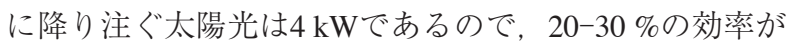
実現すれば, $1 \mathrm{~kW}$ 級のレーザーが発生する。このレー ザーによる還元を模擬するために, $1 \mathrm{~kW}$ 炭酸ガスレー ザーを用いた還元を実証した。すでに，70\%の純度で マグネシウムを生産することが可能となっており，大き なハードルは越えたと確信している。

\section{5. おわりに}

我々は，地上での太陽光励起レーザーにこだわってい るが、これには理由がある。宇宙でのレーザー発振を目 指すのも夢はあるが，限られた予算をこれに費やすのは 無駄としかいいようがない. 全世界で使用している電力 は年間18兆kWhである。100万kWの発電所にして2000基 分である.100万kWのレーザーが宇宙に浮かぶ姿を想像 しょう. $30 \%$ の効率と考えても, 太陽受光面積は, $2 \mathrm{~km}$ 四方必要となる。市販のフレネルレンズはピッチ 幅が 0.1 から $0.5 \mathrm{~mm}$ の間なので, 厚さも同程度以上必要 となる。また，ピッチ幅が小さいと散乱が増え集光効率 が低下するために，避けなければならない。そうする と, 厚さはどうしても $1 \mathrm{~mm}$ 以上は必要であろう.

レンズの厚さを $1 \mathrm{~mm}$ とすると集光レンズだけで 4000 トンの重量となる。現在, 作られている国際宇宙ステー ションが500トン程度であり, この建設に10年を要して いる，それでは，4000トンの集光系を2000基作るのに何 年とどのくらいの予算が必要なのだろうか. 一歩譲っ て，200基としても無理であろうが，これでも世界中の $10 \%$ 分のエネルギーしか供給できない.

それでは月の資源を取り，そこで生産すれば良いのは ないかという反論もあろう。では，38万 $\mathrm{km}$ の彼方から
地球に到達する世界中の電気に匹敵する20億 $\mathrm{kW}$ のレー ザーを受けるスリリングな世界に貴方は住みたいでしょ うか?

地球温暖化，化石燃料の枯渇は，まだ相当先の話と 思っている人が多いであろう。しかし，今から 20 年以内 には，30億人分の水が不足すると言われている。これ は，農業，工業用水を含めた量であるので，まもなく， 人類は深刻な食糧危機に見舞われることとなるであろ う。食料の60\%を輸入に頼っている我が国も深刻な打 撃を受けるであろう。この水不足に対して，逆浸透膜が それを解決するかのような報道が目立つが, 逆浸透膜 で，30億人分の水を作るには，9兆Whの電気が必要で ある。これは，世界中で使われている電気18兆 $\mathrm{kWh}$ $50 \%$ あるる。

我々は，この水を太陽熱で海水から精製する装置を完 成させた。 1 年間必要な 30 億人分の水は 1.5 兆トンである が，この中には，20億トンのマグネシウムが含まれてい る。世界で年間使用されている石炭・石油が100億トン なので，5年でこれに匹敵するリサイクル燃料が手に入 ることになる(Fig. 3参照).

さらに詳しい解説は，日経サイエンス ${ }^{6)}$ とPHP新書 ${ }^{7)}$ ご覧ください.

\section{参考文献}

1）矢部 孝, 内田成明, 生田一成, 吉田國雄 : 学術月報 59-2 (2006) 125.

2) T. Yabe et. al.: Appl. Phys. Lett. 89 (2006) 261107.

3) T. Yabe et. al.: Appl. Phys. Lett. 90 (2007) 261120.

4) O. Graydon: Nature Photonics 1 (2007) 495.

5) T. Ohkubo et. al.: Opt. Lett. 34 (2009) 175.

6) 矢部孝：日経サイエンス 2007年11月号, p. 30

7）矢部孝，山路達也：マグネシウム文明論一石油に代わる 新エネルギー資源－(PHP新書，2009）。 